University of Nebraska - Lincoln

DigitalCommons@University of Nebraska - Lincoln

U.S. Environmental Protection Agency Papers

U.S. Environmental Protection Agency

2008

\title{
Eutrophication and harmful algal blooms: A scientific consensus
}

J. Heisler

U.S. EPA

P. M. Glibert

University of Maryland Center for Environmental Science, glibert@hpl.umces.edu

J. M. Burkholder

North Carolina State University at Raleigh

D. M. Anderson

Woods Hole Oceanographic Institution

W. Cochlan

San Fransico State University

See next page for additional authors

Follow this and additional works at: https://digitalcommons.unl.edu/usepapapers

Heisler, J.; Glibert, P. M.; Burkholder, J. M.; Anderson, D. M.; Cochlan, W.; Dennison, W. C.; Dortch, Q.;

Gobler, C. J.; Heil, C. A.; Humphries, E.; Lewitus, A.; Magnien, R.; Marshall, H. G.; Sellner, K.; Stockwell, D. A.; Stoecker, D. K.; and Suddleson, M., "Eutrophication and harmful algal blooms: A scientific consensus" (2008). U.S. Environmental Protection Agency Papers. 169.

https://digitalcommons.unl.edu/usepapapers/169

This Article is brought to you for free and open access by the U.S. Environmental Protection Agency at DigitalCommons@University of Nebraska - Lincoln. It has been accepted for inclusion in U.S. Environmental Protection Agency Papers by an authorized administrator of DigitalCommons@University of Nebraska - Lincoln. 


\section{Authors}

J. Heisler, P. M. Glibert, J. M. Burkholder, D. M. Anderson, W. Cochlan, W. C. Dennison, Q. Dortch, C. J. Gobler, C. A. Heil, E. Humphries, A. Lewitus, R. Magnien, H. G. Marshall, K. Sellner, D. A. Stockwell, D. K. Stoecker, and M. Suddleson 


\title{
Eutrophication and harmful algal blooms: A scientific consensus
}

\author{
J. Heisler ${ }^{\mathrm{a}, 3}$, P.M. Glibert ${ }^{\mathrm{b}, *}$, J.M. Burkholder ${ }^{\mathrm{c}}$, D.M. Anderson ${ }^{\mathrm{d}}$, W. Cochlan ${ }^{\mathrm{e}}$, W.C. Dennison ${ }^{\mathrm{b}}$, \\ Q. Dortch ${ }^{\mathrm{f}}$, C.J. Gobler ${ }^{\mathrm{g}}$, C.A. Heil ${ }^{\mathrm{h}, 1}$, E. Humphries ${ }^{\mathrm{i}}$, A. Lewitus ${ }^{\mathrm{j}, \mathrm{k}, 2}$, R. Magnien ${ }^{\mathrm{l}, 2}$, \\ H.G. Marshall ${ }^{\mathrm{m}}$, K. Sellner ${ }^{\mathrm{n}}$, D.A. Stockwell ${ }^{\mathrm{o}}$, D.K. Stoecker ${ }^{\mathrm{b}}$, M. Suddleson ${ }^{\mathrm{f}}$
}

\author{
${ }^{a}$ U.S. EPA, Oceans and Coastal Protection Division, Marine Pollution Control Branch, 1200 Pennsylvania Avenue, N.W., Washington, DC 20460, United States \\ ${ }^{\mathrm{b}}$ University of Maryland Center for Environmental Science, Horn Point Laboratory, PO Box 775, Cambridge, MD 21613, United States \\ ${ }^{\mathrm{c}}$ Center for Applied Aquatic Ecology, North Carolina State University, Raleigh, NC 27695, United States \\ d Biology Department, Woods Hole Oceanographic Institution, Woods Hole, MA 02543, United States \\ e Romberg Tiburon Center for Environmental Studies, San Francisco State University, Tiburon, CA 94920, United States \\ ${ }^{\mathrm{f}}$ National Oceanic and Atmospheric Administration, 1305 East West Highway, Silver Spring, MD 20910, United States \\ ${ }^{\mathrm{g}}$ School of Marine and Atmospheric Sciences, Stony Brook University, Stony Brook, NY 11794, United States \\ ${ }^{\mathrm{h}}$ College of Marine Science, University of South Florida, St. Petersburg, FL 33701, United States \\ ${ }^{\mathrm{i}}$ Delaware Department of Natural Resources and Environmental Control, Division of Water Resources, Dover, DE 19901, United States \\ ${ }^{\mathrm{j}}$ Belle W. Baruch Institute of Marine Science and Coastal Research, and University of South Carolina, Baruch Marine Laboratory, Georgetown, SC 29442, United States \\ ${ }^{\mathrm{k}}$ Marine Resources Research Institute, South Carolina Department of Natural Resources, Hollings Marine Laboratory, Charleston, SC 29412, United States \\ ${ }^{1}$ Maryland Department of Natural Resources, Annapolis, MD 21401, United States \\ ${ }^{m}$ Department of Biological Sciences, Old Dominion University, Norfolk, VA 23529, United States \\ ${ }^{n}$ Chesapeake Research Consortium, Edgewater, MD 21037, United States \\ ${ }^{\circ}$ Institute of Marine Science, University of Alaska Fairbanks, Fairbanks, AK 99775, United States
}

\section{A R T I C L E I N F O}

\section{Article history:}

Received 26 October 2007

Received in revised form 21 January 2008

Accepted 1 August 2008

\section{Keywords:}

Eutrophication

Harmful algal blooms

HABs

Management of nutrients

Nutrient loading

Nutrient composition

Nutrient pollution

US EPA

Water quality

\begin{abstract}
A B S T R A C T
In January 2003, the US Environmental Protection Agency sponsored a "roundtable discussion" to develop a consensus on the relationship between eutrophication and harmful algal blooms (HABs), specifically targeting those relationships for which management actions may be appropriate. Academic, federal, and state agency representatives were in attendance. The following seven statements were unanimously adopted by attendees based on review and analysis of current as well as pertinent previous data:
\end{abstract}

(1) Degraded water quality from increased nutrient pollution promotes the development and persistence of many HABs and is one of the reasons for their expansion in the U.S. and other nations;

(2) The composition-not just the total quantity-of the nutrient pool impacts HABs;

(3) High-biomass blooms must have exogenous nutrients to be sustained;

(4) Both chronic and episodic nutrient delivery promote HAB development;

(5) Recently developed tools and techniques are already improving the detection of some HABs, and emerging technologies are rapidly advancing toward operational status for the prediction of HABs and their toxins;

(6) Experimental studies are critical to further the understanding about the role of nutrients in HABs expression, and will strengthen prediction and mitigation of HABs; and

(7) Management of nutrient inputs to the watershed can lead to significant reduction in HABs. Supporting evidence and pertinent examples for each consensus statement are provided herein.

(C) 2008 Elsevier B.V. All rights reserved.

\footnotetext{
* Corresponding author. Tel.: +1 4102218422

E-mail address: glibert@hpl.umces.edu (P.M. Glibert).

${ }^{1}$ Present address: Florida Fish and Wildlife Conservation Commission, Fish and Wildlife Research Institute, 100 8th Avenue S., St. Petersburg, FL 33701, United States.

2 Present address: National Oceanic and Atmospheric Administration, 1305 East West Highway, Silver Spring, MD 20910, United States.

3 Deceased.
}

\section{Introduction}

This report represents the synopsis of a "roundtable discussion" on the links between water quality and eutrophication and the occurrence of harmful algal blooms (HABs). This meeting, 
sponsored by the US Environmental Protection Agency (US EPA), was held in Cambridge, Maryland, in January 2003, and included academic experts as well as federal, state and local agency representatives. The authors of this report represent all those in attendance; our colleague, John Heisler, who originated and guided development of the meeting and chaired the discussion group, is now deceased and this paper was written in his honor.

The goal of the meeting was to develop a set of consensus statements on presently understood relationships between eutrophication and HABs, with particular emphasis on implications for nutrient management programs. A broad definition (GEOHAB, 2001) of HABs was adopted for this purpose, including potentially toxic (both autotrophic and heterotrophic) species and high-biomass producers that can cause hypoxia and anoxia and indiscriminant mortalities of marine life after reaching dense concentrations, whether or not toxins are produced.

In advance of the meeting, succinct statements for discussion were provided to participants and a presentation was given on each statement by one member of the group. The presenter was asked to make a case "for" or "against" the given statement. In discussion, and through analysis of data and evidence presented, the goal was to accept, reject, or modify each statement so that a set of unanimously accepted statements was developed by the end of the meeting. Statements were specifically crafted so as to have management implications. The relevance and applicability for management of these consensus statements remain as valid at present as when they were developed.

One recommendation from the roundtable was to develop a GEOHAB Open Science Meeting on HABs and Eutrophication to broaden the discussion on this topic to a wider community of international participants. Such a meeting was held in 2005 and the scientific results from that meeting have been synthesized into a report (GEOHAB, 2006) and some of those results are further detailed in the other papers of this issue of Harmful Algae.

Herein, each consensus statement is summarized along with a synopsis of its rationale and examples of supporting evidence. These synopses are not intended to be thorough reviews. In keeping with the mission of the US EPA, the sponsoring agency for this roundtable, preference is given to US examples where available. It is recognized that, in some cases, significant new data have become available since the 2003 roundtable. This report generally uses examples presented in the roundtable and only provides new results where advancements in the field have been substantial.

\section{The consensus statements}

\subsection{Degraded water quality from increased nutrient pollution} promotes the development and persistence of many HABs, and is one of the reasons for their expansion in the U.S. and other nations

It is generally recognized that there have been more coastal algal blooms, often of greater geographic extent and/or longer duration, with more toxic species observed, more fisheries affected, and higher associated costs from HABs in the past decade than in previous decades (Anderson, 1989; Smayda, 1990; Hallegraeff, 1993; Anderson et al., 2002; Glibert et al., 2005a). Many possible reasons for the reported global expansion exist in addition to nutrient pollution. Species dispersal or introduction, through transport of cells or cysts, can occur via natural currents and storms or human activities such as dispersal by ballast water exchange or shellfish seeding operations by which algal cells or cysts may be transported. Both overfishing and increased aquaculture alter food webs which may, in turn, alter the community of grazers that feed on HABs. Finally, improved

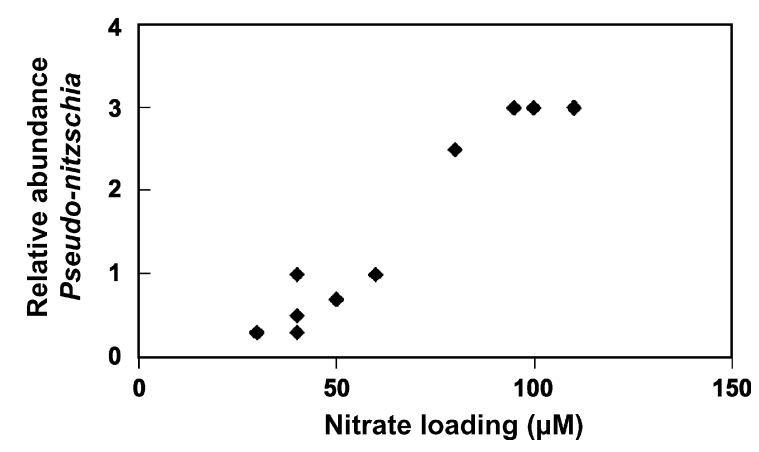

Fig. 1. Relative abundance (\%) of the diatom Pseudo-nitzschia in the sedimentary record as a function of the nitrate loading in the northern Gulf of Mexico (redrawn from Turner and Rabalais, 1991 and Parsons et al., 2002).

observation and tools for detection have increased public and scientific awareness (GEOHAB, 2001, HARRNESS, 2005). More than one cause is frequently involved, and the causes for global expansion of a given species can differ among species.

There are numerous examples worldwide of increases in HABs linked to increased nutrient loading, a few of which are highlighted here. While strong relationships have been shown for many years in freshwater ecosystems between phosphorus loadings and harmful cyanobacteria blooms (Schindler, 1977; Burkholder, 2002), increasing linkages between nutrient loading and estuarine/coastal marine HABs have more recently been recognized (Smayda, 1990, 1997; Anderson et al., 2002; Glibert et al., 2005a,b; Glibert and Burkholder, 2006). For example, in the Gulf of Mexico, the sedimentary record of concentration of potentially toxic diatoms, Pseudo-nitzcschia spp., increased in parallel to increased nitrate loading over the past several decades (Fig. 1; Turner and Rabalais, 1991, Parsons et al., 2002). In Puget Sound, Washington, USA, a strong correlation has been reported between the increase in documented levels of paralytic shellfish toxins (PST) from toxic dinoflagellates over four decades and the increase in human population in the counties bordering Puget Sound (based on US census statistics; Fig. 2; Trainer et al., 2003). Although, as above, a statistical correlation does not establish a causal link, this relationship suggests that coastal eutrophication may be a causative agent of change (Trainer et al., 2003). Blooms off the coast of China, involving Prorocentrum sp., Karenia mikimotoi and other species, have expanded during recent years in geographic extent and duration, from $\mathrm{km}^{2}$ to tens of $\mathrm{km}^{2}$, and from days to months, related to the increase in fertilizer use over the past two

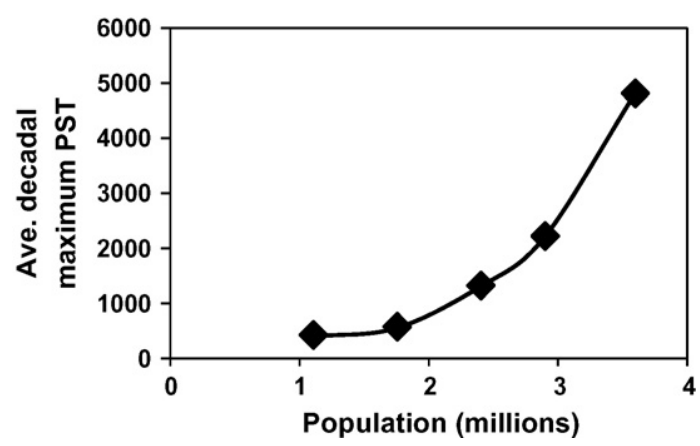

Fig. 2. Relationship between the growth in human population and the average decadal maximum paralytic shellfish toxins (PST) from dinoflagellate HABs from Puget Sound, Washington State, where continuous monitoring of paralytic shellfish poisoning has been ongoing since the mid-1950s. Human population data for the counties bordering Puget Sound for the past 40 years were derived from the U.S. census (redrawn from Trainer et al., 2003). 


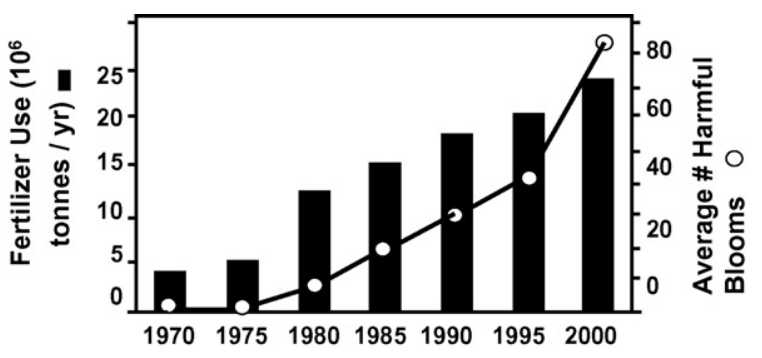

Fig. 3. Long-term trends in the use of nitrogen-based fertilizers and the number of occurrences of red tide blooms in Chinese coastal waters (modified and redrawn from Anderson et al., 2002; Zhou, 2005).

decades (Fig. 3; Anderson et al., 2002; Zhou, 2005). The Baltic Sea, Aegean Sea, Northern Adriatic, and Black Seas have all sustained increases in HABs coincident with increases in nutrient loading (e.g., Larsson et al., 1985; Bodenau, 1993; Moncheva et al., 2001). On a shorter time scale, Beman et al. (2005) reported, during a 5year study, a strong positive relationship between nitrogen-rich agricultural runoff to the Gulf of California and the development, within days, of extensive phytoplankton blooms. In Sequim Bay, Washington, an intense bloom of the toxigenic diatom Pseudonitzschia pseudodelicatissima was found a week after elevated ammonium levels were reported in these waters (Trainer et al., 2007), and similarly, in Chesapeake Bay, blooms of Prorocentrum minimum have been found to follow within days of elevated levels of urea following agricultural applications (Glibert et al., 2001).

Although such field examples, supported by experimental and physiological data (e.g., Riegman, 1995; Bates et al., 1998; Imai et al., 1998; Smayda, 1998; Johansson and Granéli, 1999; Li et al., 2001; Fan et al., 2003; Glibert et al., 2006b), are increasing, recognition that degraded water quality from nutrient pollution contributes to the development and persistence of many HABs does not diminish the possibility that other factors may promote some HABs. Physical, biological, and other chemical factors may modulate harmful algal species' responses to nutrient loadings (e.g., Vadstein et al., 2004; Gobler et al., 2002; Sellner et al., 2003; Glibert et al., 2005a), and this complexity of HAB dynamics is a challenge for their management, as further described below.

\subsection{The composition - not just the total quantity - of the nutrient pool impacts $H A B S$}

Specific algal species or species groups have numerous physiological adaptations that permit them to exploit nutrients differentially. Different species groups display preferences for specific nutrient regimes, including nutrient ratio or form (Smayda, 1990, 1997; Anderson et al., 2002; Smayda and Reynolds, 2001, 2003; Glibert and Burkholder, 2006). For example, diatoms require silicon for their growth, whereas certain dinoflagellates apparently have a higher phosphorus requirement than some other species groups. Thus, according to the nutrient ratio hypothesis (Tilman, 1977; Smayda, 1990, 1997), if nutrient loading leads to a proportional enrichment of phosphorus relative to silicon, then a proportional shift away from a diatom-dominated community toward flagellates might be expected over time.

The relationship between alteration in nutrient composition and the development of HABs is supported by examples in freshwaters, estuaries and marine coastal waters worldwide (reviewed by Anderson et al., 2002). Off the coast of Germany, time series analysis of nutrient concentrations over several decades showed that a fourfold increase in the N:Si ratio coincided with decreased abundance of diatoms and an increase in Phaeocystis blooms (Radach et al., 1990). Similarly, a nearly four-decade time series from Narragansett Bay, Rhode Island, shows a relationship between increases in the $\mathrm{N}: \mathrm{Si}$ ratio and a proportional increase in flagellates (Smayda et al., 2004). Decreases in N:P ratios due to phosphorus loading have sometimes been related to increased abundance of certain harmful dinoflagellate species. For example, in Tolo Harbor, Hong Kong, where phosphorus loading increased due to human population growth in the late 1980s, a shift from diatoms to dinoflagellates was observed, coincident with a decrease in the ambient $\mathrm{N}: \mathrm{P}$ ratio from ca. 20:1 to <10:1 (Hodgkiss and Ho, 1997; Hodgkiss, 2001). On shorter time scales, in Tunisian aquaculture lagoons, blooms of toxic dinoflagellates have been shown to develop when the $\mathrm{N}: \mathrm{P}$ ratio drops in autumn (Romdhane et al., 1998), and along the eastern seaboard of the US, outbreaks of the toxic dinoflagellates, Pfiesteria piscicida and P. shumwayae, have been associated with low dissolved $\mathrm{N}: \mathrm{P}$ ratios from high phosphate loading by effluent spills from concentrated animal operations (Burkholder et al., 1997). Blooms of Karenia brevis on the western Florida shelf are also found in waters with lower dissolved inorganic N:P ratios than in water directly to the south with higher $\mathrm{N}: \mathrm{P}$ ratios, where diatoms tend to be more prevalent (Fig. 4; Heil et al., 2007).

The impacts of varying nutrient composition on HAB proliferation, however, are in many cases more complicated than the above examples. Some studies have shown, for example, that neither the quantity nor the ratio of inorganic nutrients alone can adequately explain sustained high biomass blooms of extended duration (e.g., Vargo et al., 2004). We now recognize that inorganic nutrients are not the only nutrients used by many HABs, and that many organic nutrients are bioavailable and dynamic in their composition (e.g., Seitzinger et al., 2002; Berman and Bronk, 2003). Many HAB genera, including dinoflagellates, cyanobacteria, and pelagophytes (e.g., brown tides), can use organic (dissolved or particulate) forms of nutrients for some or all of their nitrogen, phosphorus and/or carbon demands (e.g., Paerl, 1988; Burkholder and Glasgow, 1997; Granéli et al., 1997, 1999; Berg et al., 1997, 2002; Lewitus et al., 1999; Stoecker, 1999; Kudela and Cochlan, 2000; Berman, 2001; Glibert et al., 2001, 2006a,b, 2007; Lomas et al., 2001, 2004; Mulholland et al., 2002, 2004; Gobler et al., 2005; Glibert and Legrand, 2006; Lewitus, 2006; Herndon and Cochlan, 2007; Kudela et al., 2008; Cochlan et al., 2008).

Nutrient "packaging" can also be important. For example, many flagellate species, including various harmful dinoflagellates, are mixotrophic or heterotrophic phagotrophs, and consume predominantly particulate rather than dissolved nutrients (e.g., Nygaard and Tobiesen, 1993; Stoecker, 1999; Jeong et al., 2005). Thus, the toxic, heterotrophic dinoflagellate Pfiesteria spp. can be indirectly stimulated by inorganic nutrient enrichment, mediated through an increase in the abundance of algal prey that may be directly stimulated by specific nutrient forms (Burkholder et al., 2001; Glibert et al., 2006a). Similarly, Karlodinium veneficum may be stimulated by the growth of cryptophytes, the abundance of which may be influenced by its preferred nutrient forms (Adolf et al., this issue).

Furthermore, some cyanobacteria also have the ability to convert or "fix" gaseous nitrogen into reduced nitrogen, enabling them to succeed in nitrogen-depleted conditions if other environmental conditions permit their growth (Howarth et al., 1988). The dynamics of nitrogen fixation by the cyanobacterium Trichodesmium have been related to increases in dissolved organic nitrogen which is released from the cyanobacteria and which may be available for subsequent uptake by dinoflagellates (e.g. Capone et al., 1994; Glibert and Bronk, 1994; Glibert and O'Neil, 1999; Lenes et al., 2001; Mulholland et al., 2004). Thus, nutrient ratios based solely on dissolved inorganic nutrients often do not yield sufficient insights regarding the influences of nutrient enrichment. 


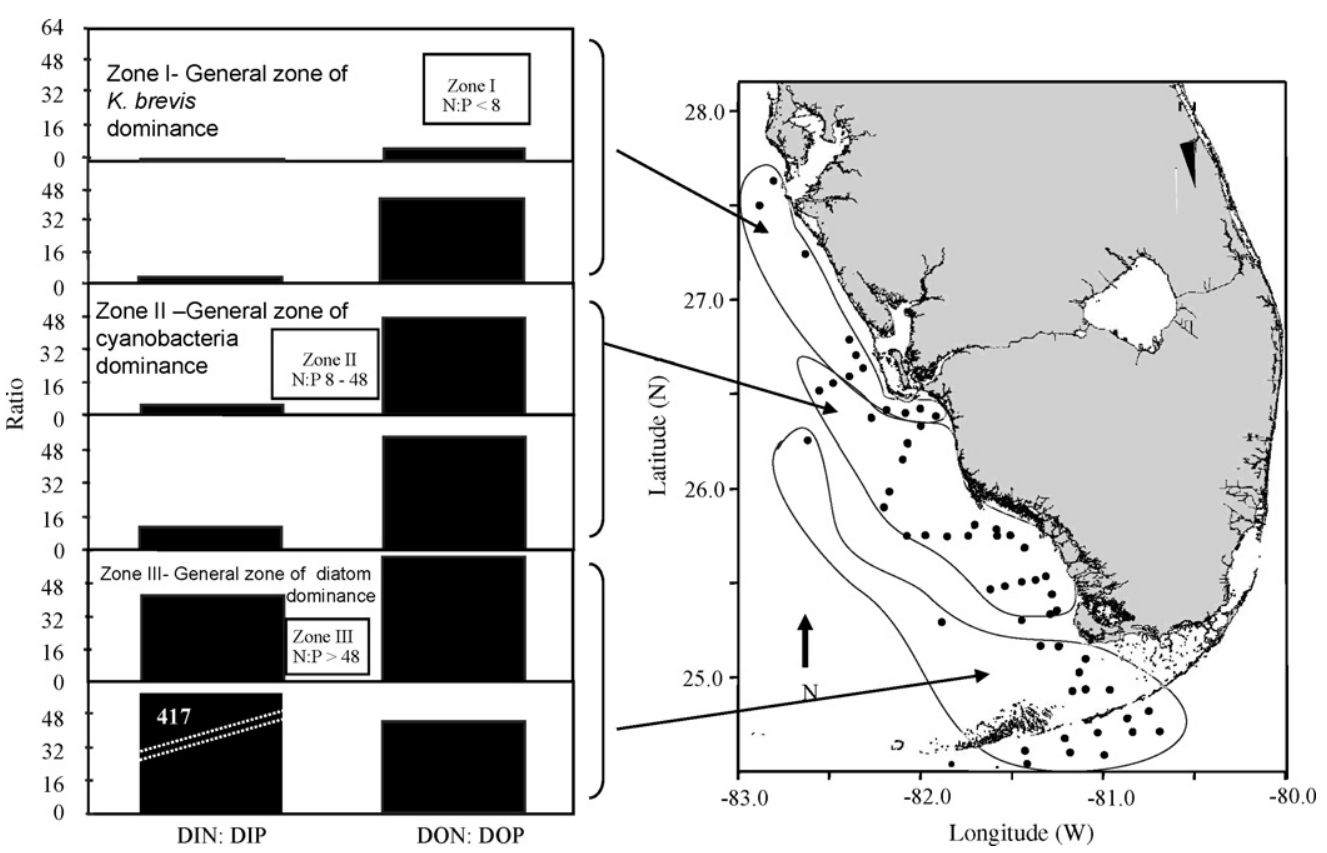

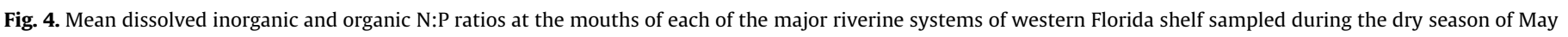

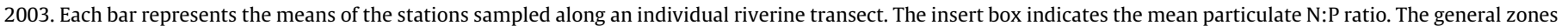
are indicated on the companion map of southern Florida (modified from Heil et al., 2007).

Toxin production may also vary with nutrient form. For example, laboratory studies have revealed that the neurotoxin domoic acid (DA) production by the diatom Pseudo-nitszchia spp. can vary as a function of the nitrogen substrate being utilized for growth. For exponentially growing cultures of $P$. australis, nitrate and ammonium-grown cells produce equivalent amounts of dissolved and particulate DA, whereas DA production is enhanced in cultures growing solely on urea (Cochlan et al., 2005, ArmstrongHoward et al., 2007). However, for the smaller-celled species, $P$. cuspidata, the nitrate-grown cells are the most toxic (Auro, 2007).

In addition to macronutrients, micronutrients such as trace metals are essential for the growth of all phytoplankton and play critical roles in both photosynthesis and assimilation of essential macronutrients, and the toxicity of some HAB species (Sunda, 2006). For example, laboratory studies have shown that the toxigenic diatoms Pseudo-nitszchia multiseries and $P$. australis produce increasing amounts of DA as a function of iron or copper limitation (Rue and Bruland, 2001; Maldonado et al., 2002; Wells et al., 2005). Additionally, it has been seen that DA production in these diatoms increases under high copper concentrations, presumably to detoxify copper (Maldonado et al., 2002; Ladizinsky, 2003; Ladizinsky et al., 2005). Iron, besides being essential for phytoplankton growth and nitrogen assimilation, is also required for nitrogen fixation, and therefore the deposition of iron-rich dust in the Gulf of Mexico has been related to the strength of Trichodesmium blooms and, indirectly, to subsequent $K$. brevis blooms (e.g., Lenes et al., 2001).

In summary, nutrient preferences by different algal species groups are strongly supported by physiological evidence and by recognition of an array of adaptive mechanisms used by different species. The extent to which these adaptations are expressed depends on other environmental conditions at the time of nutrient supply, the types of nutrient supplied and other factors, including the micronutrient environment. The inability to apply a single criterion, such as the nutrient ratio, to an assessment of phytoplankton species dominance does not negate the utility of this approach; rather, it underscores the complexity of the physiology of many HAB species and the interdependence of environmental factors in the outcome of species succession (Glibert and Burkholder, 2006).

\subsection{High-biomass blooms must have exogenous nutrients to be sustained}

Algal proliferations, by definition, are due to increased net growth, and this must be accomplished either through increases in gross growth rate and/or through reductions in loss processes such as grazing (Harris, 1986). "New" nutrients from allochthonous sources can fuel biomass increases. While increased total algal biomass is often an obvious response to nutrient loading (see reviews in Cloern, 2001; Anderson et al., 2002), the overall speciesspecific response will depend upon the physiology of the organisms present, environmental conditions, and the form of nutrient supplied, as described above. Clear dose-response relationships between nutrient loading and biomass response (typically termed a "phase I" eutrophication model sensu Cloern, 2001 ) are more common in lakes, however, than in estuarine and marine systems.

The relationships between nutrient loading and algal proliferations are complicated by shifts in food webs, habitat changes, climate changes and other system alterations that affect the extent to which a given species may accumulate (typically termed a "phase II" model of eutrophication; Cloern, 2001). Increased nutrient enrichment can lead to a shift in plankton community composition, which in turn can afect predator-prey relationships, further altering the transfer of nutrients (e.g., Smayda, 1989; MacIntyre et al., 2004; Irigoien et al., 2005; Mitra and Flynn, 2006; Sunda et al., 2006). Incoming nutrients may be regenerated, recycled, or removed in space and time from the set of conditions that would otherwise support blooms. These links are frequently difficult to establish.

Inside blooms, ambient concentrations of inorganic nutrient forms may be reduced or depleted due to algal incorporation of the nutrients into biomass (e.g., Vargo et al., 2004; Springer et al., 
2005), leading to relationships between nutrient concentration and chlorophyll (or other biomass indicator) that may, in fact, appear to follow a saturation response, a negative relationship, or no relationship at all. Thus, the critical term is the flux of nutrient, not the absolute concentration that may be supporting the blooms.

The most complex nutrient sources to understand and regulate are non-point source inputs such as runoff, groundwater and atmospheric deposition. The relationship between increased exogenous inputs and increased algal biomass is often clearer over long time periods. Nitrogen loading, for example, in the Chesapeake Bay, which increased more than 2.5-fold from the mid1940 s to the mid-1990s, has been correlated with long-term increases in total chlorophyll, in the frequency and abundance of blooms of HAB species such as $P$. minimum, and in resulting hypoxic volume (Hagy et al., 2004; Kemp et al., 2005).

While exogenous nutrients are often necessary for high biomass blooms to be sustained, in some cases, blooms may be sustained on nutrients that are regenerated and recycled after an initial injection of new nutrients. Long-term sustained blooms, such as the bloom of Aureoumbra lagunensis evident in Laguna Madre for approximately 8 years in the 1990s, and the $>20$ month bloom of $K$. brevis that was sustained off western Florida in 2005, appear to have been fueled by an initial injection of nutrients, and then sustained on regenerated nutrients. In the former case, intense rains after years of drought led to a sequence of blooms and ecosystem conditions suitable for Aureoumbra (e.g., Buskey et al., 2001), while in the latter case, a series of hurricanes in preceding months may also have altered both nutrient availability and other habitat considerations (Mallin and Corbett, 2006; Neely et al., 2006). A third such example is that of the $>18$ months bloom of Synechococcus in eastern Florida Bay that followed an injection of phosphorus from two apparent sources: high freshwater discharge from Hurricanes Katrina, Rita and Wilma that impacted south Florida in 2005 , and a very high organic loading from a unique situation of road construction that required mulching of significant amounts of mangroves (Madden, in press). Consequently, chlorophyll concentrations rose and were sustained at levels roughly eightfold higher than pre-bloom levels, while an increase in phosphorus concentration was only observed during the initiation stages of the bloom and then declined. A final example comes from brown tides (Aureococcus anophagefferens) in US mid-Atlantic estuaries (Gobler et al., 2005). These blooms are often preceded by a 'pre-bloom' of other algal species that are stimulated by nitrogen from groundwater flow (Gobler and Sañudo-Wilhelmy, 2001). When groundwater flow diminishes during summer and the initial bloom is remineralized, organic nitrogen levels increase, and $A$. anophagefferens becomes the dominant alga. Thus, nutrients may continue to serve as fuel for blooms long after the initial nutrient loading occurs.

\subsection{Both chronic and episodic nutrient delivery promote $H A B$ development}

As described in some of the previous examples, the response of harmful algal species to changes in nutrient enrichment is often a chronic effect, becoming increasingly apparent only after long time intervals are examined (e.g., Lam and Ho, 1989; Smayda, 1989; Riegman et al., 1993; Yung et al., 1997; Marshall et al., 2005). Long-term, consistent monitoring records additionally can reveal relationships between harmful algal species composition and abundance versus other aspects of environmental change, such as climate variability or alterations in trophic control due to changes in dominant herbivorous species. Such long-term records are valuable in clarifying trends in nutrient loadings, and in identifying synergistic effects of changing climatic factors and nutrient enrichment (e.g., Smayda et al., 2004, Burkholder et al., 2006).

Episodic or "pulsed" nutrient inputs have also been related to outbreaks of harmful algal species on both small and large scales. Some of these, such as agricultural applications (timing and quantity), treated sewage discharge, and combined sewer outfalls, are amenable to management. As examples (reviewed in Harlin, 1993), in Boston Harbor, sea lettuce (Ulva) formed dense populations for many years near outfalls of poorly treated sewage. Along the intertidal area of the Baltic Sea, sewage inputs have been related to overgrowth of formerly dominant brown seaweeds (Fucus spp.) by opportunistic macroalgae. Episodic inputs resulting from storm events are, naturally, more difficult to manage.

Episodic storm events and climate variability affect the timing of freshwater flow, residence times, the magnitude and timing of nutrient pulses and resulting biotic responses (e.g., Miller et al., 2006; Burkholder et al., 2006; Mallin and Corbett, 2006; Paerl et al., 2006). In coastal lagoons, where riverine input is not the dominant source of nutrient delivery, climate variability can alter the input of groundwater nutrients (e.g., LaRoche et al., 1997). Hurricane Isabel in 2003 caused a large phytoplankton bloom to develop in Chesapeake Bay within days (Miller et al., 2005). Further, extensive hypoxia occurred in the lagoonal Neuse River Estuary after Hurricanes Dennis and Floyd, whereas a storm that caused less flooding, Hurricane Fran, led to more concentrated pollutants, extensive anoxia and massive fish kills (Burkholder et al., 2006). In the Choptank River subestuary of Chesapeake Bay, annual spring blooms of $P$. minimum generally follow within days of spring agricultural application of nitrogen fertilizer and its runoff from episodic spring rains (Glibert et al., 2001).

In some cases anthropogenic nutrients may not directly stimulate HABs, but may become linked to their growth and abundance following biogeochemical processing or following the stimulation of other components of the food web on which they may depend.

On a seasonal scale in Chesapeake Bay, USA, nutrient input in the spring is delivered largely in the form of nitrate and rapidly assimilated by diatoms which bloom, then sink and decompose as nutrients become depleted. Subsequently during warmer summer months, nitrogen, largely as ammonium, is released via decomposition in sedimentary processes which, in turn, supports an assemblage dominated by flagellates including potentially harmful dinoflagellates (Glibert et al., 1995; Malone et al., 1996; Kemp et al., 2005).

It is thus important in our interpretation of the relationships between nutrients and HAB occurrences that we move away from simplistic inorganic nutrient-dose-yield models and begin to incorporate nutrient loading parameters which encompass the increasing array of nutrient forms that are now recognized to be important. Furthermore, interpretations of nutrient effects on HABs as well as models that parameterize these relationships, need to incorporate indirect, time-lagged nutrient pathways, as well as the feedbacks and interactions of the effects of nutrient loads in ecosystems (Cloern, 2001).

2.5. Recently developed tools and techniques are already improving the detection of some HABs, and emerging technologies are rapidly advancing toward operational status for the prediction of HABs and their toxins

Due to the unpredictability of most episodic events, sampling programs historically have not "captured" the initiation phases of blooms. However, new in situ monitoring tools are beginning to permit resolution of the antecedent conditions and the time course response to some episodic events. Improved molecular probes, some 
that can be incorporated into in situ microarrays, are allowing timely detection of cells. Molecular probes for individual HAB species and their toxins are now routinely applied for many species, making early detection possible (e.g., Scholin and Anderson, 1998; Scholin et al., 2003; Anderson et al., 2005a; Bowers et al., 2006). Optical sensors for Karenia species have been deployed on moorings and autonomous underwater vehicles (Schofield et al., 1999). In situ probes with telemetry for various key variables such as temperature, salinity, chlorophyll, turbidity, dissolved oxygen and pHs are also providing near-real time data for management applications (Glasgow et al., 2004; Springer et al., 2005). A suite of over 50 such probes in the State of Maryland are allowing managers and the public alike to monitor trends in Chesapeake Bay and rapidly respond when conditions warrant (www.eyesonthebay.net). In situ nutrient sensors are also advancing, with capability developing for some organic forms of nutrients as well as inorganic forms, so that relationships between pulses in nutrient delivery and alterations in salinity due to rainfall, for example, are now possible to establish (Glibert et al., 2005b, 2008).

In conjunction with the growing sophistication of tools, better citizen awareness and citizen monitoring can also be effective in capturing blooms or blooms conditions. Throughout the US and in many parts of the world, fishermen collect samples for cell and nutrient analyses, and local citizen groups and indigenous people participate in routine monitoring (e.g., Scaefer et al., 2004; Trainer and Suddleson, 2005; Whereat and Farestad, 2005; Granéli and Esplund, 2006).

Modeling is a rapidly developing tool advancing toward prediction of many HAB species and occurrences (e.g., Flynn, 2002; McGillicuddy et al., 2005; Hood et al., 2006), although for most estuarine and coastal HABs, prediction has not yet been attained (see, e.g., Franks, 1997; Cembella, 1998; Flynn, 2005). There are two general types of HAB models that are useful for management applications. The first is the development of models that predict "general likelihood of occurrence" of HAB species, whereas the second is the development of models that include "explicit" predictions of HAB occurrence in time or space. The former is useful for management in application of long-term actions to reduce the likelihood of future occurrences, i.e. prevention. The latter requires more refinement to understand the physics, biology and chemistry of the environment, but it can be of more value at the local community level. Models of a range of types are useful in predicting general likelihood of occurrence, from simple regression models that may yield correlation (without necessarily a biological foundation for cause and effect) and conceptual models that are useful in communicating general patterns (e.g., Smayda and Reynolds, 2001, 2003). In advancing toward more explicit predictions, mechanistic models that describe the physical, chemical and biological interactions are required. Spatially explicit models linked to hydrodynamic models are yielding some success in retrospectively tracking some species, such as for Alexandrium spp. in the Gulf of Maine and K. brevis in the Gulf of Mexico (McGillicuddy et al., 2005, Walsh et al., 2006). Multi-parameter physiological models that incorporate various organismal life stages and trophic interactions are also beginning to be developed (J. Anderson et al., 2003; D. Anderson et al., 2005b; Hood et al., 2006).

The development of explicit, reliable model predictions still needed for most HABs will require significant data on the species of interest as well as the environmental conditions (Flynn, 2002, 2005). Thus, for some species, "general likelihood" predictions are viable now and can be useful in guiding long-term management decisions with respect to nutrients. Furthermore, several types of real-time and near-real-time monitoring systems, coupled with conceptual, statistical, or mechanistic models, are also available now to assist in detecting and predicting some HABs in time and space. Now-cast models are being developed in the Chesapeake, Bay, for example, of the likelihood for $K$. veneficum blooms based on a statistical habitat relationship of the $\mathrm{HAB}$ with salinity and temperature, and a hydrodynamic model (Ramers et al., 2003; Tango et al., 2005). However, the prediction "window" for those species for which such mechanistic models are available is presently short, and considerable work will be needed to strengthen insights about the relationships between nutrient responses, physical dynamics, and climate change. Application of real-time monitoring of both environmental parameters and HABs species will continue to advance forecasting capabilities for these dynamic relationships.

\subsection{Experimental studies are critical for further understanding about the role of nutrients on HABs expression, and will strengthen prediction and mitigation of $H A B S$}

Many physiological adaptations to nutrients are best examined under controlled laboratory conditions. For example, assessments of specific relationships that are required in models (such as parameters of nutrient uptake and growth kinetics) are better resolved under laboratory conditions where a culture of known physiological state can be established and where environmental conditions can be rigorously set (e.g., Lomas et al., 1996; Fan et al., 2003; Glibert et al., 2006b; Herndon and Cochlan, 2007; Cochlan et al., 2008). Laboratory culture studies of HAB species have been instrumental in resolving such species characteristics as life histories, toxigenesis, ecophysiological responses to specific nutrient forms, light and temperature regimes, and speciesspecific differences in rates of nutrient uptake and growth. As new insights are developed about various processes - for example, the extent of osmotrophy or mixotrophy within a species generalizations based upon older laboratory data may have to be revisited, cross-confirmed, or assessed anew.

A critical but often overlooked consideration regarding experimental work is that major characteristics of species maintained in culture for extended periods (months to years) significantly change over time under (highly artificial) enclosed conditions. Over time in culture, highly toxic strains have lost their ability to make toxin; strains also have changed in polyploidy, expression of life history stages, and responses to environmental conditions such as salinity and nutrient regimes (reviewed in Wood and Leatham, 1992; Burkholder and Glibert, 2006). Pfiesteria spp., for example, have been shown to loose their toxicity when switched from a media that includes live to one with algal prey (Burkholder et al., 2001). Toxin production in a strain of Alexandium lusitanicum was also shown to loose toxicity after many years in culture, and although the exact reasons could not be ascertained, genetic mutations or prolonged use of antibiotics may have been the cause (Martins et al., 2004).

Many species have shown strain differences unrelated to extended period in culture. For example, Strom and Bright (2003) observed that strains of the haptophyte Emiliania huxleyii varied in their response to different forms of nitrogen. Whereas all four strains tested grew on nitrate and ammonium, three of the four could grow on organic nitrogen sources, while the fourth could not. The strains also showed distinct responses to various forms of organic nitrogen. Thus, in conducting laboratory studies, the history of the culture should be carefully considered (e.g., location of isolation and duration in culture). It is also important to compare multiple strains of the same species to assess whether the characteristic of concern is strain-specific, and generalizations at the species level (or higher) based upon one to a few strains should be avoided (Burkholder and Glibert, 2006; Burkholder et al., 2001, 2005). 
Experiments should continue to build upon the knowledge gained from unialgal culture studies to assessment of more complex systems with multiple species, from microcosms to mesocosms, and from laboratory studies to field trials. Mesocosm studies and field experiments, if carefully designed and controlled, can enable in situ assessment of processes of trophodynamics and community interactions with individual species (e.g., Stoecker and Gustafson, 2002), and the importance of environmental fluctuations in light, temperature, and community-level responses to nutrient enrichment. Such approaches have significantly advanced understanding of nutrient limitation. As examples, the classic whole-lake studies undertaken decades ago in Canada yielded tremendous insights about phosphorus limitation in freshwater systems (Schindler, 1987, 2006). Analogously, much was learned about the regulation of marine phytoplankton production by iron in the multiple in situ iron enrichment experiments conducted in the high-nutrient-low-chlorophyll (HNLC) regions of the world (reviewed by de Baar et al., 2005). Smaller-scale mesocosms also have helped to resolve nutrient preferences by the harmful brown tide species, A. anophagefferens (Kana et al., 2004) and the effects of trophic structure on top-down regulation of phytoplankton biomass (Glibert, 1998; Granéli and Turner, 2002; Buskey et al., 2003; Vadstein et al., 2004).

As model sophistication and insights continue to develop about the dynamic regulation of adaptive characteristics of individual species, there will be a ongoing need to experimentally document specific processes under controlled conditions with clonal algal isolates, both as individual species ( \pm bacteria, e.g., Bates et al., 1995; Burkholder et al., 2005) and as mixes of species in an increasingly complex but controlled environment (e.g., Flynn, 2002). Based upon the major insights gained from previous experiments, the data from such controlled conditions will surely strengthen scientists' abilities to predict and mitigate HABs.

\subsection{Management of nutrient inputs to the watershed can lead to significant reductions in $H A B S$}

There are now multiple examples demonstrating both total algal biomass and $\mathrm{HAB}$ occurrence decreases after reduction in nutrient input. One of the classic examples involving decreases in cyanobacterial blooms is that of the removal of sewage discharges from Lake Washington within metropolitan Seattle, Washington (Edmondson, 1970). This lake had sustained noxious cyanobacteria blooms from the 1920s through the 1960s because of raw sewage inputs. An elimination of sewage discharges to Lake Washington was imposed in 1968, and the cyanobacterial blooms declined. In a much larger system, Lake Erie, the green macroalga Cladophora had choked much of the west basin with massive growth until improved wastewater treatment and detergent phosphate bans in the early 1980s led to significant reduction in the nuisance blooms (Ashworth, 1986). Reduced nutrient loading similarly has promoted declines in estuarine and marine coastal HABs. Sewage discharges to Mumford Cove, a shallow estuary in Connecticut, were re-routed to another waterway in the late 1980s, and within 2 years massive nuisance blooms of the macroalga, Ulva lactuca, were eliminated (Harlin, 1993). In the Potomac River, a tributary of Chesapeake Bay, phosphate removal from sewage in the late $1970 \mathrm{~s}$ was related to significant reductions in the frequency and intensity of Microcystis blooms that had been problematic in the previous decade (Jaworski, 1990). In the Seto Inland Sea in Japan between 1965 and 1976, the number of red tide outbreaks (high biomass blooms) increased sevenfold (Okaichi, 1997), in parallel with the increase in industrial production, but in 1973, Japanese authorities instituted the Seto Inland Sea Law to reduce loadings to half of the 1974 levels over a 3-year period. The number of red tides began to

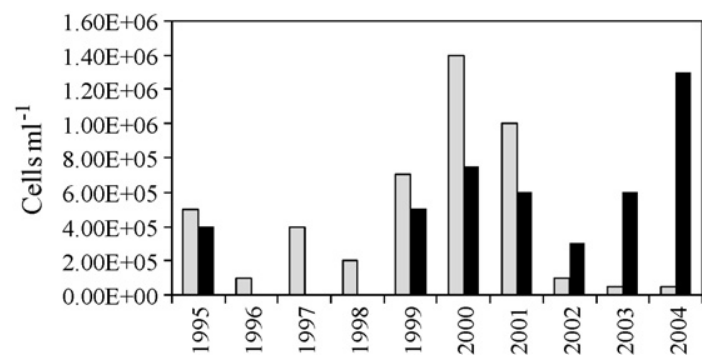

Fig. 5. Long-term trends in brown tide events in Peconic Estuary Long Island (gray bars) and in Maryland Coastal Bays (black bars; redrawn from Gobler et al., 2005; Glibert et al., 2007).

decrease in 1977 , eventually falling to less than $30 \%$ of the peak frequency, which had been in excess of 300 blooms year $^{-1}$ (reviewed by Imai et al., 2006).

A more recent example appears to be that of the Long Island brown tides which, while so common in the early 1990s, were virtually absent from the Long Island embayments through the middle of the following decade (Fig. 5; Gobler et al., 2005). Although multiple factors have been suggested to be related to the decline in bloom intensity, the recent reductions in nitrogen levels in Peconic Estuary have been correlated with these declines (Nuzzi and Waters, 2004; Gobler et al., 2005). Blooms of A. anophagefferens are generally reliant on organic sources of nitrogen for growth (Dzurica et al., 1989; Lomas et al., 1996; Berg et al., 1997, 2002; Mulholland et al., 2002, 2004). In the Long Island embayments, the organic sources fueling these blooms are not thought to be a direct external nutrient source, but rather derive from the internal processing of other "new" nitrogen sources, including groundwater flow, which is elevated in nitrate. This nitrate delivery supports blooms of diatoms, as well as blooms of benthic microalgae which, as they begin to dissipate, can supply the necessary organic nitrogen for the brown tide (Gobler and SañudoWilhelmy, 2001; MacIntyre et al., 2004; Gobler et al., 2005). From 1995 to 2006, levels of DON declined substantially and brown tides were absent from the Peconic Bays during those years (Gobler et al., 2005). In sharp contrast, however, in Maryland embayments, where brown tide also blooms, organic nutrient concentrations have been increasing annually over the past decade, leading to more significant blooms each year over the decade from the mid1990s to the mid-2000s (Trice et al., 2004; Glibert et al., 2007).

Although these specific examples suggest that some successes may be possible in reducing incidences of HABs by reducing nutrient inputs, for many species these relationships may be complex. Long time scales may be involved, due to long-term storage of nutrient in sediments and alteration in the biogeochemistry of systems after years of nutrient loading (e.g., Kemp et al., 2005). Furthermore, for some systems, ecosystem dynamics may be permanently altered, and nutrient reduction strategies alone will not yield original ecosystem conditions. Eutrophication stressors such as loss of benthic habitat, development of hypoxia/ anoxia, and alterations in food webs (Cloern, 2001) require long time scales for restoration and may require changes at the landscape scale.

With increasing pressures on the coastal landscape, it must be underscored that prevention of large blooms through nutrient control is far preferable than attempts to eradicate HABs once they are established. It is, however, a significant challenge and extremely costly to enact such policy decisions on large-scale nutrient reductions, so there will continue to be pressure to develop bloom control strategies. Furthermore, different nutrient actions may be required for different types of HABs, and organic as well as inorganic nutrients must be considered. Effective manage- 
ment is an iterative process, involving adaptive management as new knowledge is gained, and must be sustained to be effective. Lastly, timely communication of results, to stakeholders and the public, is critical. Given projected increases in human population worldwide, eutrophication pressures and increased HAB occurrences will undoubtedly continue to increase in years to come.

\section{Acknowledgements}

The "roundtable" discussion which forms the basis of this paper was funded by the US EPA. Meeting support was provided by Battelle. J. Hawkey assisted with logistics and graphics. PMG's time to prepare this manuscript was provided by grant NAO4NOS4780241 from NOAA MERHAB. This is contribution number 4120 from the University of Maryland Center for Environmental Science and MERHAB contrubution number 58.[SS]

\section{References}

Adolf, J.E., Bachvaroff, T., Place, A.R., this issue. Cryptophyte abundance drives blooms of mixotrophic harmful algae: a hypothesis based on Karlodinium veneficum as a model system, Harmful Algae.

Anderson, D.M., 1989. Toxic algal bloom and red tides: a global perspective. In: Okaichi, T., Anderson, D.M., Nemoto, T. (Eds.), Red Tides: Biology, Environmental Science and Technology. Elsevier, pp. 11-16.

Anderson, D.M., Glibert, P.M., Burkholder, J.M., 2002. Harmful algal blooms and eutrophication: nutrient sources, composition and consequences. Estuaries 25, 562-584.

Anderson, D.M., Kulis, D., Keafer, M., Gribble, B.A., Marin, K.E., Scholin, R., 2005a. C.A. Identification and enumeration of Alexandrium spp. from the Gulf of Maine using molecular probes. Deep-Sea Res. II 19-21, 2467-2490.

Anderson, D.M., Stock, C.A., Keafer, B.A., Bronzino Nelson, A., Thompson, B., McGillicudy, D.J., Keller, M., Matria, P.A., Martin, J., 2005b. Alexandrium fundyense cyst dynamics in the Gulf of Maine. Deep-Sea Res. II 52 (19-21), 2522-2542.

Anderson, J.T., Hood, R.R., Zhang, X., 2003. Quantification of Pfiesteria piscicida growth and encystment parameters using a numerical model. Mar. Ecol. Prog. Ser. 246, 105-113.

Armstrong-Howard, M.D., Cochlan, W.P., Ladzinsky, N.L., Kudela, R.M., 2007. Nitrogenous preference of toxogenic Pseudo-nitzschia australis (Bacillariophyceae) from field and laboratory experiments. Harmful Algae 6, 206-217.

Ashworth, W., 1986. The Late, Great Lakes. Collins Publishers, Toronto, Ontario, 274 pp.

Auro, M.E., 2007. Nitrogen dynamics and toxicity of the pennate diatom Pseudonitzschia cuspidata: a field and laboratory study. M.S. Thesis, San Francisco State University, San Francisco, California, USA, 91 p.

Bates, S.S., Douglas, D.J., Doucette, G.J., Leger, C., 1995. Enhancement of domoic acid production by reintroducing bacteria to axenic cultures of the diatom Pseudonitzschia multiseries. Nat. Toxins 3, 428-435.

Bates, S.S., Garrison, D.L., Horner, R.L., 1998. Bloom dynamics and physiology of domoic-acid-producing Pseudo-nitzschia species. In: Anderson, D.M., Cembella, A.D., Hallegraeff, G.M. (Eds.), Physiological Ecology of Harmful Algal Blooms. NATO ASI Series, vol. G 41. Springer-Verlag, Berlin, pp. 131-267.

Beman, J.M., Arrigo, K.R., Matson, P.A., 2005. Agricultural runoff fuels large phytoplankton blooms in vulnerable areas of the ocean. Nature 434, 211-214.

Berg, G.M., Glibert, P.M., Lomas, M.W., Burford, M., 1997. Organic nitrogen uptake and growth by the chrysophyte Aureococcus anophagefferens during a brown tide event. Mar. Biol. 129, 377-387.

Berg, G.M., Repeta, D.J., LaRoche, J., 2002. Dissolved organic nitrogen hydrolysis rates in axenic cultures of Aureococcus anophagefferens (Pelagophyceae): comparison with heterotrophic bacteria. Appl. Environ. Microbiol. 401-404, doi:10.1128/AEM.68.1.401-404.2002.

Berman, T., 2001. The role of DON and the effect of N:P ratios on occurrence of cyanobacterial blooms: implications from the outgrowth of Aphanizomenon in Lake Kinneret. Limnol. Oceanogr. 46, 443-447.

Berman, T., Bronk, D.A., 2003. Dissolved organic nitrogen: a dynamic participant in aquatic ecosystems. Aquat. Microb. Ecol. 31, 79-305.

Bodenau, N., 1993. Microbial blooms in the Romanian area of the Black Sea and contemporary eutrophication conditions. In: Smayda, T.J., Shimizu, Y. (Eds.), Toxic Phytoplankton Blooms in the Sea. Elsevier, Amsterdam, pp. 203-209.

Bowers, H.A., Trice, T.M., Magnien, R.E., Goshorn, D.M., Michael, B., Schaefer, E.F., Rublee, P.A., Oldach, D.A., 2006. Detection of Pfiesteria spp. in surface sediments collected from Chesapeake Bay tributaries (Maryland). Harmful Algae 5, 342-351.

Burkholder, J.M., 2002. Cyanobacteria. In: Bitton, G. (Ed.), Encyclopedia of Environmental Microbiology. Wiley Publishers, New York, pp. 952-982.

Burkholder, J.M., Dickey, D.A., Kinder, C., Reed, R.E., Mallin, M.A., Melia, G., McIver, M.R., Cahoon, L.B., Brownie, C., Deamer, N., Springer, J., Glasgow Jr., H., Toms, D. Smith, J., 2006. Comprehensive trend analysis of nutrients and related variables in a large eutrophic estuary: a decadal study of anthropogenic and climatic influences. Limnol. Oceanogr. 51, 463-487.
Burkholder, J.M., Gordon, A.S., Moeller, P.D., Law, J.M., Coyne, K.J., Lewitus, A.J. Ramsdell, J.S., Marshall, H.G., Deamer, N.J., Cary, S.C., Kempton, J.W., Morton, S.L., Rublee, P.A., 2005. Demonstration of toxicity to fish and to mammalian cells by Pfiesteria species: comparison of assay methods and multiple strains. Proc. Natl. Acad. Sci. U.S.A. 102, 3471-3476.

Burkholder, J.M., Glasgow, H.B., 1997. Pfiesteria piscicida and other Pfiesteria-like dinoflagellates: behavior, impacts and environmental controls. Limnol. Oceanogr. 42, 1052-1075.

Burkholder, J.M., Glasgow Jr., H.B., Deamer-Melia, N.J., Springer, J., Parrow, M.W., Zhang, C., Cancellieri, P., 2001. Species of the toxic Pfiesteria complex, and the importance of functional type in data interpretations. Environ. Health Perspect. 109, 667-679.

Burkholder, J.M., Glibert, P.M., 2006. Intraspecific variability: an important consideration in forming generalizations about toxigenic algal species. African J. Mar. Sci. 28, 177-180.

Burkholder, J.M., Mallin, M.A., Glasgow Jr., H.B., Larsen, L.M., Mclver, M.R., Shank, G.C., Deamer-Melia, N., Briley, D.S., Springer, J., Touchette, B.W., Hannon, E.K., 1997. Impacts to a coastal river and estuary from rupture of a large swine waste holding lagoon. J. Environ. Qual. 26, 1451-1466.

Buskey, E.J., DeYoe, H., Jochem, F.J., Villareal, T.A., 2003. Effects of mesozooplankton removal and ammonium additions on planktonic trophic structure during a bloom of the Texas "brown tide", a mesocosm study. J. Plank. Res. 25, 215-228.

Buskey, E.J., Liu, H., Collumb, C., Bersano, J.G.F., 2001. The decline and recovery of a persistent Texas brown tide algal bloom in the Laguna Madre (Texas, USA). Estuaries 24, 337-346.

Capone, D.G., Ferrier, M.D., Carpenter, E.J., 1994. Amino acid cycling in colonies of the planktonic marine cynaobacterium Trichodesmium theibautii. Appl. Environ. Microbiol. 60, 3989-3995.

Cembella, A.D., 1998. Ecophysiological processes and mechanisms: towards common paradigms for harmful algal blooms. In: Anderson, D.M., Cembella, A.D., Hallegraeff, G.M. (Eds.), Physiological Ecology of Harmful Algal Blooms. NATO ASI Series 41. Springer, Berlin, Heidelberg, New York, pp. 381403.

Cloern, J.E., 2001. Our evolving conceptual model of the coastal eutrophication problem. Mar. Ecol. Prog. Ser. 210, 223-253.

Cochlan, W.P., Herndon, J., Kudela, R.M., 2008. Inorganic and organic nitrogen uptake by the toxigenic diatom Pseudo-nitzschia australis (Bacillariophyceae). Harmful Algae 8, 111-118.

Cochlan W.P., Herndon J., Ladizinsky N.L., Kudela RM., 2005. Nitrogen uptake by the toxigenic diatom Pseudo-nitzschia australis. GEOHAB Open Science Meeting: HABs and Eutrophication, Baltimore, MD, USA.

de Baar, H.J.W., Boyd, P.W., Coale, K.H., Landry, M.R., Tsuda, A., Assmy, P., Bakker D.C.E., Bozee, Y., Barbe, R.T., Brzezinski, M.A., Buesseler, K.O., Boyé, M., Croot P.L., Gervais, F., Gorbunov, M.Y., Harrison, P.J., Hiscock, W.T., Laan, P., Lancelot, C., Law, C.S., Levasseur, M., Marchetti, A., Millero, F.J., Nishioka, J., Nojiri, Y., van Oijen, T., Riebesell, U., Rijkenberg, M.J.A., Saito, H., Takeda, S., Timmermans, K.R., Veldhuis, M.J.W., Waite, A.M., Wong, C.-S., 2005. Synthesis of iron fertilization experiments: from the Iron Age in the Age of Enlightenment. J. Geophys. Res. 110, C09S16, doi:10.1029/2004JC002601.

Dzurica, S., Lee, C., Cosper, E.M., Carpenter, E.J., 1989. Role of environmental variables, specifically organic compounds and micronutrients, in the growth of the chrysophyte Aureococcus anophagefferens, the "brown tide" microalga. In: Cosper, E.M., Bricelj, V.M., Carpenter, E.J. (Eds.), Novel Phytoplankton Blooms. Coastal and Estuarine Studies No. 35. Springer-Verlag, New York, pp. 511-541.

Edmondson, W.T., 1970. Phosphorus, nitrogen and algae in Lake Washington after diversion of sewage. Science 169, 690-691.

Fan, C., Glibert, P.M., Burkholder, J.M., 2003. Characterization of the nitrogen uptake kinetics of Prorocentrum minimum in natural blooms and laboratory cultures. Harmful Algae 2, 283-299.

Flynn, K.J., 2002. Modeling marine phytoplankton growth under eutrophic conditions. J. Sea Res. 54, 92-103.

Flynn, K.J., 2005. Castles built on sand: dysfunctional plankton models and the failure of the biology-modeling interface. J. Plank. Res. 27, 1205-1210.

Franks, P.J.S., 1997. Models of harmful algal blooms. Limnol. Oceanogr. 42, 12731282.

GEOHAB (Global Ecology and Oceanography of Harmful Algal Blooms Programme), 2001. Science Plan. Glibert, P., G. Pitcher (eds.). SCOR and IOC, Baltimore, MD and Paris, France.

GEOHAB (Global Ecology and Oceanography of Harmful Algal Blooms Programme), 2006. HABs in Eutrophic Systems. P. Glibert (ed). IOC and SCOR, Paris and Baltimore. 74 pp.

Glasgow, H.B., Jr. Burkholder, J.M., Reed, R.E., Lewitus, A.J., Kleinman, J.E., 2004. Realtime remote monitoring of water quality: a review of current applications, and advancements in sensor, telemetry, and computing technologies. J. Exp. Mar. Biol. Ecol. 300, 409-448.

Glibert, P.M., 1998. Interactions of top-down and bottom-up control in planktonic nitrogen cycling. Hydrobiologia 363, 1-12.

Glibert, P.M., Anderson, D.A., Gentien, P., Granéli, E., Sellner, K.G., 2005a. The global, complex phenomena of harmful algal blooms. Oceanography 18 (2), 136-147.

Glibert, P.M., Bronk, D.A., 1994. Release of dissolved organic nitrogen by the marine diazotrophic cyanobacterium Trichodesmium spp. Appl. Environ. Microbiol. 60, 3996-4000.

Glibert, P.M., Burkholder, J.M., 2006. The complex relationships between increasing fertilization of the Earth, coastal eutrophication, and HAB proliferation. In: 
Granéli, E., Turner, J. (Eds.), The Ecology of Harmful Algae. Springer-Verlag, New York, pp. 341-354.

Glibert, P.M., Burkholder, J.M., Parrow, M.W., Lewitus, A.J., Gustafson, D.E., 2006b. Direct uptake of nitrogen by Pfiesteria piscicida and Pfiesteria shumwayae, and nitrogen nutritional preferences. Harmful Algae 5, 380-394.

Glibert, P.M., Conley, D.J., Fisher, T.R., Harding Jr., L.W., Malone, T.C., 1995. Dynamics of the 1990 winter/spring bloom in Chesapeake Bay. Mar. Ecol. Prog. Ser. 122 22-43.

Glibert, P.M., Harrison, J., Heil, C., Seitzinger, S., 2006a. Escalating worldwide use of urea-a global change contributing to coastal eutrophication. Biogeochemistry 77, 441-463.

Glibert, P.M., Kelly, V., Alexander, J., Codispoti, L.A., Boicourt, W.C., Trice, T.M. Michael, B., Wazniak, C., 2008. In situ nutrient monitoring-a tool for capturing ephemeral nutrient pulses. Harmful Algae 8, 175-181.

Glibert, P.M., Legrand, C., 2006. The diverse nutrient strategies of HABs: focus on osmotrophy. In: Granéli, E., Turner, J. (Eds.), Ecology of Harmful Algae. Springer pp. 163-176.

Glibert, P.M., Magnien, R., Lomas, M.W., Alexander, J., Fan, C., Haramoto, E., Trice T.M., Kana, T.M., 2001. Harmful algal blooms in the Chesapeake and Coasta Bays of Maryland, USA: comparisons of 1997, 1998, and 1999 events. Estuaries 24, 875-883.

Glibert, P.M., O’Neil, J., 1999. Dissolved organic nitrogen release and amino acid oxidase activity by Trichodesmium spp. In: Charpy, L., Larkum, A.W.D. (Eds.), Marine Cyanobacteria. Monaco Musée Océanographique, Bulletin de l'Institut Océanographique, Monaco, pp. 265-272.

Glibert, P.M., Seitzinger, S., Heil, C.A., Burkholder, J.M., Parrow, M.W., Codispoti, L.A. Kelly, V., 2005b. The role of eutrophication in the global proliferation of harmful algal blooms: new perspectives and new approaches. Oceanography 18 (2), 198-209.

Glibert, P.M., Wazniak, C.E., Hall, M., Sturgis, B., 2007. Seasonal and interannual trends in nitrogen and brown tide in Maryland's Coastal Bays. Ecol. Appl. 17, S79-S87.

Gobler, C.J., Lonsdale, D.J., Boyer, G.L., 2005. A synthesis and review of causes and impact of harmful brown tide blooms caused by the alga, Aureococcus anophagefferens. Estuaries 28, 726-749.

Gobler, C.J., Renaghan, M.J., Buck, N.J., 2002. Impacts of nutrients and grazing mortality on the abundance of Aureococcus anophagefferens during a New York brown tide bloom. Limnol. Oceanogr. 47, 129-141.

Gobler, C.J., Sañudo -Wilhelmy, S.A., 2001. Temporal variability of groundwater seepage and brown tide blooms in a Long Island embayment. Mar. Ecol. Prog. Ser. 217, 299-309.

Granéli, E., Anderson, D.M., Carlsson, P., Maestrini, S.Y., 1997. Light and dark carbon uptake by Dinophysis species in comparison to other photosynthetic and heterotrophic dinoflagellates. Aquat. Microb. Ecol. 13, 177-186.

Granéli, E., Carlsson, P., Legrand, C., 1999. The role of C, N and P in dissolved and particulate matter as a nutritional source for phytoplankton growth, including toxic species. Aquat. Ecol. 33, 17-27.

Granéli, E., Esplund, C., 2006. Minimizing economical losses with "real-time" HAB surveillance. In: 12th International Conference on Harmful Algae. Copenhagen, Denmark, September (abstract only).

Granéli, E., Turner, J.T., 2002. Top-down regulation in ctenophore-copepod-ciliatediatom-phytoflagellate communities in coastal waters: a microcosm study. Mar. Ecol. Prog. Ser. 239, 57-68.

Hagy, J.D., Voynton, W.R., Keefe, C.W., Wood, K.V., 2004. Hypoxia in Chesapeake Bay, 1950-2001: long-term change in relation to nutrient loading and river flow. Estuaries 27, 634-658.

Hallegraeff, G.M., 1993. A review of harmful algal blooms and their apparent global increase. Phycologia 32, 79-99.

Harlin, M.M., 1993. Changes in major plant groups following nutrient enrichment In: McComb, J. (Ed.), Eutrophic Shallow Estuaries and Lagoons. CRC Press, Inc. Boca Raton, pp. 173-187.

Harris, G.P., 1986. Phytoplankton Ecology: Structure, Function, and Fluctuation. Chapman and Hall.

HARRNESS (Harmful Algal Research and Response: A National Environmental Science Strategy), 2005. Ramsdell, J., Anderson, D., P. Glibert (eds.). Ecologica Society of America, Washington DC.

Heil, C.A., Revilla, M., Glibert, P.M., Murasko, S., 2007. Nutrient quality drives phytoplankton community composition on the West Florida Shelf. Limnol. Oceanogr. 52, 1067-1078.

Herndon, J., Cochlan, W.P., 2007. Nitrogen utilization by the raphidophyte Heterosigma akashiwo: growth and uptake kinetics in laboratory cultures. Harmful Algae 6, 260-270.

Hodgkiss, I.J., 2001. The N:P ratio revisited. In: Ho, K.C., Wang, Z.D. (Eds.), Prevention and Management of Harmful Algal Blooms in the South China Sea. School of Science and Technology, the Open University of Hong Kong.

Hodgkiss, I.J., Ho, K.C., 1997. Are changes in N:P ratios in coastal waters the key to increased red tide blooms? Hydrobiologia 852, 141-147.

Hood, R.R., Zhang, X., Glibert, P.M., Roman, M.R., Stoecker, D.K., 2006. Modeling the influence of nutrients, turbulence and grazing on Pfiesteria population dynamics. Harmful Algae 5, 459-479.

Howarth, R.W., Marino, R., Lane, J., Cole, J.J., 1988. Nitrogen fixation in freshwater, estuarine, and marine ecosystems. I. Rates and importance. Limnol. Oceanogr. 33, 669-687.

Imai, I., Yamaguchi, M., Hori, Y., 2006. Eutrophication and occurrences of harmful algal blooms in the Seto Inland Sea, Japan. Plankton Benthos Res. 1 (2), 71-84.
Imai, I., Yamaguchi, M., Watanabe, M., 1998. Ecophysiology, life cycle, and bloom dynamics of Chattonella in the Seto Inland Sea, Japan. In: Anderson, D.M., Cembella, A.D., Hallegraeff, G.M. (Eds.), Physiological Ecology of Harmful Phytoplankton Blooms. Springer-Verlag, Berlin, pp. 95-112.

Irigoien, X., Flynn, K.J., Harris, R.P., 2005. Phytoplankton blooms: a "loophole" in microzooplankton grazing impact? J. Plank. Res. 27, 313-321.

Jaworski, N., 1990. Retrospective of the water quality issues of the upper Potomac estuary. Aquat. Sci. 3, 11-40.

Jeong, H.J., Yoo, Y.D., Park, J.Y., Song, J.Y., Kim, S.T., Lee, S.H., Kim, K.Y., Yih, W.H., 2005. Feeding by phototrophic red-tide dinoflagellates: five species newly revealed and six species previously known to be mixotrophic. Aquat. Microb. Ecol. 40, 133-150.

Johansson, N., Granéli, E., 1999. Cell density, chemical composition and toxicity of Chrysochromulina polylepis (Haptophyta) in relation to different N:P supply ratios. Mar. Biol. 135, 209-217.

Kana, T.M., Lomas, M.W., MacIntyre, H.L., Cornwell, J.C., Gobler, C.J., 2004. Stimulation of the brown tide organism, Aureococcus anophagefferens, by selective nutrient additions to in situ mesocosms. Harmful Algae 3, 377-388.

Kemp, W.M., Boynton, W.R., Adolf, J.E., Boesch, D.F., Boicourt, W.C., Brush, G., Cornwell, J.C., Fisher, T.R., Glibert, P.M., Hagy, J.D., Harding, L.W., Houde, E.D., Kimmel, D.G., Miller, W.D., Newell, R.I.E., Roman, M.R., Smith, E.M., Stevenson, J.C., 2005. Eutrophication in Chesapeake Bay: historical trends and ecological interactions. Mar. Ecol. Prog. Ser. 303, 1-29.

Kudela, R.M., Cochlan, W.P., 2000. Nitrogen and carbon uptake kinetics and the influence of irradiance for a red tide bloom off Southern California. Aquat. Microb. Ecol. 21, 31-47.

Kudela, R.M., Lane, J.Q., Cochlan, W.P., 2008. The potential role of anthropogenically derived nitrogen in the growth of harmful algae in California, USA. Harmful Algae 8, 103-110.

Ladizinsky N.C., 2003. The influence of dissolved copper on the production of domoic acid by Pseudo-nitzschia species in Monterey Bay, California: laboratory experiments and field observations. Master's Thesis, California State University, Monterey Bay, CA, USA, 68 pp.

Ladizinsky, N.C., Smith, G.J., Coale, K.H., Cochlan, W.P., 2005. The influence of dissolved copper on the production of domoic acid by toxigenic species of Pseudo-nitzschia in Monterey Bay, California. In: GEOHAB Open Science Meeting on HABs and Eutrophication, Baltimore, MD, March, p. 2005.

Lam, C.W.Y., Ho, K.C., 1989. Red tides in Tolo Harbour, Hong Kong. In: Okaichi, T., Anderson, D.M., Nemoto, T. (Eds.), Red Tides: Biology, Environmental Science and Toxicology. Elsevier, New York, pp. 49-52.

LaRoche, J., Nuzzi, R., Waters, R., Wyman, K., Falkowski, P.G., Wallace, D.W.R., 1997. Brown tide blooms in Long Island's coastal waters linked to variability in groundwater flow. Global Change Biol. 3, 397-410.

Larsson, U., Elmgren, R., Wulff, F., 1985. Eutrophication and the Baltic Sea-causes and consequences. AMBIO 14, 9-14.

Lenes, J.M., Darrow, B.P., Cattrall, C., Heil, C.A., Callahan, M., Vargo, G.A., Byrne, R.H., Propsero, J.M., Bates, D.E., Fanning, K.A., Walsh, J.J., 2001. Iron fertilization and the Trichodesmium response on the West Florida Shelf. Limnol. Oceanogr. 46, $1261-1270$.

Lewitus, A.J., 2006. Osmotrophy in marine microalgae. In: Subba-Rao, D.V. (Ed.), Algal cultures, Analogues of blooms and applications. Science Publishers, Enfield, NH, USA, pp. 343-383.

Lewitus, A.J., Burkholder, J.M., Glasgow Jr., H.B., Glibert, P.M., Willis, B.M., Hayes, K.C., 1999. Mixotrophy and nitrogen uptake by Pfiesteria piscicida (Dinophyceae). J. Phycol. 35, 1430-1437.

Li, A., Stoecker, D.K., Coats, D.W., 2001. Mixotrophy in Gyrodinium galatheanum Dinophyceae): grazing responses to light intensity and inorganic nutrients. J. Phycol. 36, 33-45.

Lomas, M.W., Glibert, P.M., Berg, G.M., 1996. Characterization of nitrogen uptake by natural populations of Aureococcus anophagefferens (Chrysophyceae) as a function of incubation duration, substrate concentration, light, and temperature. J. Phycol. 32, 907-916.

Lomas, M.W., Glibert, P.M., Clougherty, D.A., Huber, D.R., Jones, J., Alexander, J., Haramoto, E., 2001. Elevated organic nutrient ratios associated with brown tide blooms of Aureococcus anophagefferens (Pelagophyceae). J. Plank. Res. 23, 13391344

Lomas, M.W., Kana, T.M., MacIntyre, H.L., Cornwell, J.C., Nuzzi, R., Waters, R., 2004. Interannual variability of Aureococcus anophagefferens in Quantuck Bay, Long Island: natural test of the DON hypothesis. Harmful Algae 3, 389-402.

MacIntyre, H.L., Lomas, M.W., Cornwell, J., Suggett, D.J., Gobler, C.J., Koch, E.W., Kana, T.M., 2004. Mediation of benthic-pelagic coupling by microphytobenthos: an energy-and material-based model for initiation of blooms of Aureococcus anophagefferens. Harmful Algae 3, 403-437.

Madden, C., in press. Case study: Florida Bay. In: P. Glibert, C. Madden, W. Boynton, D. Flemer, C. Heil, J. Sharp (eds.). Estuarine Nutrient Criteria Development: State of the Science 2007. EPA Office of Water.

Maldonado, M.T., Hughes, M.P., Rue, E.L., Wells, M.L., 2002. The effect of Fe and Cu on growth and domoic acid production by Pseudo-nitzschia multiseries and Pseudonitzschia australis. Limnol. Oceanogr. 47, 515-526.

Mallin, M.A., Corbett, C.A., 2006. How hurricane attributes determine the extent of environmental effects: multiple hurricanes and different coastal systems. Estuaries Coasts 29 (No. 6A), 1046-1061.

Malone, T.C., Conley, D.J., Fisher, T.R., Glibert, P.M., Harding, L.W., Seller, K.G., 1996 Scales of nutrient-limited phytoplankton productivity in Chesapeake Bay. Estuaries 19, 371-385. 
Marshall, H.G., Egerton, T., Burchardt, L., Cerbin, S., Kokocinski, M., 2005. Long-term monitoring results of harmful algal populations in Chesapeake Bay and its major tributaries in Virginia, USA. Oceanol. Hydrobiol. Stud. 34, 35-41.

Martins, C.A., Kulis, D., Franca, S., Aderson, D.M., 2004. The loss if PSP toxin production in a formerly toxic Alexandrium lusitanicum clone. Toxicon 43, 195-205.

McGillicuddy Jr., D.J., Anderson, D.M., Lynch, D.R., Townsend, D.W., 2005. Mechanisms regulating large-scale seasonal fluctuations in Alexandrium fundyense populations in the Gulf of Maine: results from a physical-biological model. Deep-Sea Res. II 52, 2698-2714.

Miller, W.D., Harding, L.W., Adolf, J.E., 2005. The influence of Hurricane Isabel on Chesapeake Bay phytoplankton dynamics. In: Sellner, K.G. (Ed.), Hurricane Isabel in Perspective,. Chesapeake Research Consortium Publication 05-160, Edgewater, MD.

Miller, W.D., Harding, L.W., Adolf, J.E., 2006. Hurrical Isabel generated an unusual fall bloom in Chesapeake Bay. Geophys. Res. Lett. 33, LO6612, doi:10.1029/ 2005GL025658.

Mitra, A., Flynn, K.J., 2006. Promotion of harmful algal blooms by zooplankton predatory activity. Biol. Lett. 2, 194-197, doi:10.1098/rsbl.2006.0447.

Moncheva, S., Gotsis-Skretas, O., Pagou, K., Krastev, A., 2001. Phytoplankton blooms in Black Sea and Mediterranean coastal ecosystems subjected to anthropogenic eutrophication: similarities and differences. Estuar. Coast. Shelf Sci. 53, 281295.

Mulholland, M.R., Gobler, C.J., Lee, C., 2002. Peptide hydrolysis, amino acid oxidation, and nitrogen uptake in communities seasonally dominated by Aureococcus anophagefferens. Limnol. Oceanogr. 47, 1094-1108.

Mulholland, M.R., Heil, C.A., Bronk, D.A., O’Neil, J.M., Bernhardt, P., 2004. Does nitrogen regeneration from the $\mathrm{N}_{2}$ fixing cyanobacteria Trichodesmium spp. fuel Karenia brevis blooms in the Gulf of Mexico? In: Steidinger, K.A., Landsberg, J.H., Tomas, C.R., Vargo, G.A. (Eds.), Harmful Algae 2002. Florida Fish and Wildlife Conservation Commission, Florida Institute of Oceanography and Intergovernmental Oceanogrpahic Commission of UNESCO, pp. 4749.

Neely, M.B., Heil, C.A., Murasko, S., Dziemiela, K., Faltin, E., Garrett, M., Truby, E., Carlson, D., English, D., 2006. HAB's and hurricanes in Florida. In: American Geophysical Union, Fall Meeting. (abstract only \#B41E-0226).

Nygaard, K., Tobiesen, A., 1993. Bacterivory in algae: a survival strategy during nutrient limitation. Limnol. Oceanogr. 38, 273-279.

Nuzzi, R., Waters, R.M., 2004. Long-term perspective on the dynamics of brown tide blooms in Long Island coastal waters. Harmful Algae 3, 279-294.

Okaichi, T., 1997. Red tides in the Seto Inland Sea. In: Okaichi, T., Yanagi, Y. (Eds.), Sustainable Development in the Seto Inland Sea-From the Viewpoint of Fisheries. Tera Sci. Publ. Co, Tokyo, Japan, pp. 251-304.

Paerl, H.W., 1988. Nuisance phytoplankton blooms in coastal, estuarine, and inland waters. Limnol. Oceanogr. 33, 823-847.

Paerl, H., Valdes, L.M., Peierls, B.L., Adolf, J.E., Harding, L.W., 2006. Anthropogenic and climatic influences on the eutrophication of large estuarine systems. Limnol. Oceanogr. 51, 448-462.

Parsons, M.L., Dortch, Q., Turner, R.E., 2002. Sedimentological evidence of an increase in Pseudo-nitzschia (Bacillariophyceae) abundance in response to coastal eutrophication. Limnol. Oceanogr. 47, 551-558.

Radach, G., Berg, J., Hagmeier, E., 1990. Long-term changes of the annual cycles of meteorological, hydrographic, nutrient and phytoplankton time series at Helgoland and at V ELBE 1 in the German Bight. Contin. Shelf Res. 10, 305-328.

Ramers, D.L., Brown, C.W., Tango, P.J., 2003. Predicting the abundance of the dinoflagellate Karlodinium micrum in Chesapeake bay using an artificial neural network. EOS, Transactions AGU, 84 (52), Ocean Sci., Meeting Suppl. Abstract OS21E-04.

Riegman, R., 1995. Nutrient-related selection mechanism in marine phytoplankton communities and the impact of eutrophication on the planktonic food web. Water Sci. Technol. 32, 63-75.

Riegman, R., Row, A., Noordeloos, A.A.M., Cadee, G.C., 1993. Evidence for eutrophication induced Phaeocystis sp. blooms in the Narsdiep area (The Netherlands). In: Smayda, T.J., Shimizu, Y. (Eds.), Toxic Phytoplankton Blooms in the Sea. Elsevier Science, New York, pp. 799-805.

Romdhane, M.S., Eilertsen, H.C., Yahia, O.K.D., Yahia, M.N.D., 1998. Toxic dinoflagellate blooms in Turisian lagoons: causes and consequences for aquaculture. In: Reguera, B., Blanco, J., Fernández, M.L., Wyatt, T. (Eds.), Harmful Algae. Xunta de Galicia and Intergovernmental Oceanographic Commission of UNESCO, Vigo, pp. 80-83.

Rue, E., Bruland, K., 2001. Domoic acid binds iron and copper: a possible role for the toxin produced by the marine diatom Pseudo-nitzschia. Mar. Chem. 76, 127134.

Scaefer, K.A., Blankenstein, H.L., Nowocin, K.J., Morton, S.L., 2004. The use of volunteers to monitor harmful phytoplankton. In: Steidingner, K.A., Landsberg, J.H., Tomas, C.R., Vargo, G.A. (Eds.), Harmful Algae 2002. Florida Fish and Wildlife Conservation Commission, Florida Institute of Oceanography and Intergovernmental Oceanographic Commission of UNESCO, pp. 323-325.

Schindler, D.W., 1977. Evolution of phosphorus limitation in lakes. Science 196, 260-262.

Schindler, D.W., 1987. Determining ecosystem responses to anthropogenic stress. Can. J. Fish. Aquat. Sci. 44 (Suppl. 1), 6-25.

Schindler, D.W., 2006. Recent advances in the understanding and management of eutrophication. Limnol. Oceanogr. 51, 356-363.
Schofield, O.M., Grzymski, J., Bisset, W.P., Kirkpatrick, G.J., Millie, D.F., Moline, M. Roesler, C.S., 1999. Optical monitoring and forecasting systems for harmful algal blooms: possibility or pipe dream? J. Phycol. 35 (6), 1476-1496.

Scholin, C.A., Anderson, D.M., 1998. Detection and quantification of HAB species using antibody and DNA probes: progress to date and future research objectives. In: Requera, B., Blanco, J., Fernandez, M.L., Wyatt, T. (Eds.), Harmful Algae. IOC UNESO, Paris, pp. 253-257.

Scholin, C., Vrieling, E., Peperzak, L., Rhodes, L., Rublee, P.A., 2003. Detection of HAB species using lectin, antibody, and DNA probes. In: Hallegraeff, G.M., Anderson, D.M., Cembella, A.D. (Eds.), Manual on Harmful Marine Microalgae. 2nd ed. UNESCO Monographs on Oceanographic Methodology, Paris, France, pp. 131 164.

Sellner, K.G., Doucette, G.J., Kirkpatrick, G.J., 2003. Harmful algal blooms: causes, impacts and detection. J. Ind. Microbiol. Biotechnol. 3, 383-406.

Seitzinger, S.P., Sanders, R.W., Styles, R.V., 2002. Bioavailability of DON from natural and anthropogenic sources to estuarine plankton. Limnol. Oceanogr. 47 (2), 353-366.

Smayda, T.J., 1989. Primary production and the global epidemic of phytoplankton blooms in the sea: a linkage? In: Cosper, E.M., Bricelj, V.M., Carpenter, E.J. (Eds.), Novel Phytoplankton Blooms Coastal and Estuarine Studies No. 35. Springer-Verlag, New York, pp. 449-484.

Smayda, T.J., 1990. Novel and nuisance phytoplankton blooms in the sea: evidence for a global epidemic. In: Granéli, E., Sundstrom, B., Edler, L., Anderson, D.M. (Eds.), Toxic Marine Phytoplankton. Elsevier, New York, pp. 29-40.

Smayda, T.J., 1997. Harmful phytoplankton blooms: their ecophysiology and general relevance. Limnol. Oceanogr. 42, 1137-1153.

Smayda, T.., 1998. Ecophysiology and bloom dynamics of Heterosigma akashiwo (Raphidophyceae). In: Anderson, D.M., Cembella, A.D., Hallegraeff, G.M. (Eds.), Physiological Ecology of Harmful Algal Blooms. NATO ASI Series, vol. G 41. Springer-Verlag, New York, pp. 113-131.

Smayda, T.J., Borkman, D.G., Beaugrand, G., Belgrano, A.G., 2004. Ecological effects of climate variation in the North Atlantic: phytoplankton. In: Stenseth, N.C., Ottersen, G., Hurrell, J., Belgrano, A. (Eds.), Ecological Effects of Climate Variations in the North Atlantic. Oxford Univ. Press, pp. 49-54.

Smayda, T.J., Reynolds, C.S., 2001. Community assembly in marine phytoplankton: application of recent models to harmful dinoflagellate blooms. J. Plank. Res. 23, 47-461.

Smayda, T.J., Reynolds, C.S., 2003. Strategies of marine dinoflagellate survival and some rules of assembly. J. Sea Res. 49, 95-106.

Springer, J.J., Burkholder, J.M., Glibert, P.M., Reed, R.E., 2005. Use of a real-time remote monitoring network and shipborne sampling to characterize a dinoflagellate bloom in the Neuse Estuary, North Carolina, USA. Harmful Algae 4 533-551.

Stoecker, D., 1999. Mixotrophy among dinoflagellates. J. Eukaryot. Microbiol. 46, 397-401.

Stoecker, D.K., Gustafson, D.E., 2002. Predicting grazing mortality of an estuarine dinoflagellate, Pfiesteria piscicida. Mar. Ecol. Prog. Ser. 233, 31-38.

Strom, S.L., Bright, K. 2003. Effects on planktonic food webs of organic nitrogen use by bloom-forming phytoplankton. Abstract in: Proceedings of the Biennial Meeting of the Estuarine Research Federation, Seattle, Washington, USA. Estuarine Research Federation, Port Republic, MD.

Sunda, W.G., 2006. Trace metals and harmful algal blooms. In: Granéli, E., Turner, J.T. (Eds.), Ecology of Harmful Algae. Springer-Verlag, Berlin, pp. 203-214.

Sunda, W.G., Granéli, E., Gobler, C.J., 2006. Positive feedback and the development and persistence of ecosystem disruptive algal blooms. J. Phycol. 42, 963974.

Tango, P., Brown, C.W., Gross, T.F., Ramers, D.L., Hood, R.R., Michael, B.D., 2005. Assessing the validation of a preliminary Karlodinium micrum nowcast model system in Chesapeake Bay and its tributaries: a framework for HAB nowcasts and forecasts. In: HABs and Eutrophication Open Science Meeting. Baltimore MD, March (abstract only).

Tilman, D., 1977. Resource competition between planktonic algae: an experimental and theoretical approach. Ecology 58, 338-348.

Trainer, V.L., Cochlan, W.P., Erickson, A., Bill, B.D., Cox, F.H., Borchert, J.A., Lefebvre, K.A., 2007. Recent domoic acid closures of shellfish harvest areas in Washington State inland waterways. Harmful Algae 6, 449-459.

Trainer, V.L., Le Eberhart, B.-T., Wekell, J.C., Adams, N.G., Hanson, L., Cox, F., Dowell, J., 2003. Paralytic shellfish toxins in Puget Sound, Washington. J. Shellfish Res. 22, 213-223.

Trainer, V.L., Suddleson, M., 2005. Monitoring approaches for early warning of domoic acid events in Washington State. Oceanography 18, 228-237.

Trice, T.M., Glibert, P.M., Lea, C., Van Heukelem, L., 2004. HPLC pigment records provide evidence of past blooms of Aureococcus anophagefferens in the Coastal Bays of Maryland and Virginia, USA. Harmful Algae 3, 295-304.

Turner, R.E., Rabalais, N., 1991. Changes in Mississippi river water quality this century and implications for coastal food webs. BioScience 41, 140-147.

Vadstein, O., Stibor, H., Lippert, B., Loseth, K., Roederer, W., Sundt-Hansen, L., Olsen, Y., 2004. Moderate increases in the biomass of omnivorous copepods may ease grazing control of planktonic algae. Mar. Ecol. Prog. Ser. 270, 199207.

Vargo, G.A., Heil, C.A., Ault, D.N., Neely, M.B., Murasko, S., Havens, J., Lester, K.M., Dixon, L.K., Merkt, R., Walsh, J., Weisberg, R., Steidinger, K.A., 2004. Four Karenia brevis blooms: a comparative analysis. In: Steidinger, K.A., Landsberg, J.A., Tomas, C.R., Vargo, G.A. (Eds.), Harmful Algae 2002 Proceedings of the Xth International Conference on Harmful Algae, Florida Fish and Wildlife 
Conservation Commission, Florida Institute of Oceanography, and the Intergovernmental Oceanographic Commission of UNESCO, St. Petersburg (FL), pp. 14-16.

Walsh, J.J., Jolliff, J., Darrow, B.P., Lenes, J.M., Milroy, S.P., Dieterle, D., Carder, K.L., Chen, F.L., Vargo, G.A., Weisberg, R.H., Fanning, K.A., Muller-Karger, F., Stieidinger, K.A., Heil, C.A., Prospero, J.S., Lee, T.N., Kirkpatrick, G., Whitledge, T.E. Stockwell, D.A., Tomas, C., Villareal, T.A., Jochems, A.E., Bontempe, P.S., 2006. Red tides in the Gulf of Mexico: where, when and why? J. Geophys. Res. 111, C11003, doi:10.1029/2004JC002813.

Wells, M.L., Trick, C.G., Cochlan, W.P., Hughes, M.P., Trainer, V.L., 2005. Domoic acid: the synergy of iron, copper, and the toxicity of diatoms. Limnol. Oceanogr. 50, 1908-1917.
Whereat, E., Farestad, M., 2005. Volunteer HAB monitoring provides a "first watch" for resource managers and researchers in the Delaware Inland Bays, USA. In: HABs and Eutrophication Open Science Meeting. Baltimore MD, March (abstract only).

Wood, A.M., Leatham, T., 1992. The species concept in phytoplankton ecology. J. Phycol. 28, 723-729.

Yung, Y.K., Wong, C.K., Broom, M.J., Ogden, J.A., Chan, S.C.M., Leung, Y., 1997. Longterm changes in hydrography, nutrients, and phytoplankton in Tolo Harbour, Hong Kong. Hydrobiologia 352, 107-115.

Zhou, M., 2005. Which is the trigger factor to the outbreak of large scale Prorocentrum blooms in the East China Sea? In: HABs and Eutrophication Open Science Meeting. Baltimore MD, March (abstract only). 